\title{
Expressed breast milk: a less used option by working mothers of India
}

\author{
Suvarna Rai* \\ Department of Obstetrics and Gynecology, Malla Reddy Institute of Medical Sciences, Hyderabad, Telangana, India
}

Received: 30 May 2017

Accepted: 03 June 2017

\section{*Correspondence:}

Dr. Suvarna Rai,

E-mail: drsuvarnarai@gmail.com

Copyright: (C) the author(s), publisher and licensee Medip Academy. This is an open-access article distributed under the terms of the Creative Commons Attribution Non-Commercial License, which permits unrestricted non-commercial use, distribution, and reproduction in any medium, provided the original work is properly cited.

\section{ABSTRACT}

Background: Expressed breast milk is a healthy feeding option as compared to formula milk for working postnatal mothers. Objective of present work was to study the knowledge, attitude and practice regarding expressed breast milk feeding among working postnatal mothers and to identify and explore the barriers against it.

Methods: A double blinded cross sectional study was conducted at a tertiary care centre in Hyderabad city, India. 100 working breastfeeding postnatal mothers with infants upto 1 year were identified. A validated questionnaire in English and Hindi was used for data collection. It constituted personal characteristics, knowledge regarding expressed breast milk feeding, attitude towards it and presently followed practices by working mothers.

Results: A total of 100 working mothers with infants less than one year were selected who attended the postnatal clinics at our hospital, a tertiary care centre in Hyderabad city. Overall, the knowledge regarding expressed breast milk feeding was unsatisfactory in $64 \%$ of women. Only $36 \%$ of them had satisfactory knowledge. Positive attitude towards expressed breast milk feeding was seen in $60 \%$ of them and $40 \%$ of them had negative attitude. Expressed breast milk feeding was practised by $11 \%$ of them, formula milk by $53 \%$, mixed feeding by $10 \%$ and cow milk by $26 \%$ as a substitute to breast feeding in their absence. Univariate analysis revealed no statistically significant determinant of their knowledge, attitude and practices.

Conclusions: Knowledge about expressed breast milk feeding in Indian working breastfeeding mothers is suboptimal. Imparting adequate knowledge can improve feeding practices.

Keywords: Expressed breast milk, Formula feeds, Pumping breast milk, Working mothers

\section{INTRODUCTION}

It is a well-known fact that breast feeding is the best method of feeding for babies both nutritionally and emotionally. ${ }^{1}$

WHO recommends exclusive breast feeding for babies up to 6 months for optimal growth and health and to continue breast feeding till 2 years or longer if the mother and child are willing. ${ }^{2,3}$ Today the commonest obstacle for this is maternal employment. ${ }^{4}$ Based on these facts, WHO also recommends countries to grant 24 weeks of maternity leave to protect maternal and child health. ${ }^{5}$ Parliament of India passed an amendment to the
Maternity Benefit Bill (2016) stating every organisation (public or private) with more than fifty female employees should grant 26 weeks maternity leave to all working mothers in their organisation. Sadly, many organisations are yet to implement it. In such a scenario and after 26 weeks of maternity leave, working mothers have to make a difficult choice regarding feeding options for their babies. Breastfeeding is undoubtedly the best form of feeding. Breast milk is the best nutritional choice for infants and it is possible to administer it even in the absence of the mother during feeds by pumping and storing and using it as and when required. A simpler alternative is Formula feeds. Formula milk provides babies with the nutrients they need to grow and thrive. ${ }^{6}$ 
They have become a popular choice among Indian women who are away from their babies for 6-8 hrs duration. Quite in contrast is the situation in developed nations where working mothers who breast feed usually opt for this method when they return to work. ${ }^{7,8}$ The present study aims at finding out reasons for the same.

\section{METHODS}

The present study was a double blinded cross-sectional study conducted at Malla Reddy Institute of medical Sciences, a tertiary care centre at the city of Hyderabad, India. All mothers who attended the postnatal clinic with infants upto 1 year of age were identified. Of these mothers who were working for 6-8 hrs in a day were included in the study as study population. Those mothers who left their babies elsewhere and were not living with them presently, those with HIV and Hepatitis B positive status and women who did not want to be a part of this study were excluded. Thus 100 postnatal breastfeeding working women were finally shortlisted and interviewed by the interviewer using a validated questionnaire in either English or Hindi whichever the woman was comfortable with to understand and reply. The questionnaire consisted of four parts. First part collected all the personal characteristics information like age of the mother, age of the infant, Educational qualification of the mother, Socio economic status, hospital where mother delivered, Mother's Occupation, Organisation with which the mother was working, number of hours of work, present method of feeding in the absence of mother as a substitute to breast feeding.

Second part included questions that tested mothers' knowledge about expressed breast feeding like if breast milk can be expressed, stored and used for feeding at a later date, duration it can be stored at room temperature for, duration of storage at refrigerator, duration of storage in deep freezer, equipment for pumping, equipment for storing expressed breast milk and method of thawing expressed breast milk. Questions also checked if mothers knew about benefits of breast milk as compared to formula milk. A correct response was scored as 1 and a wrong or not aware response as 0 . The higher the score, the better knowledge it reflected. A score above $50 \%$ was considered satisfactory, that below $50 \%$ was considered unsatisfactory.

The third part of the questionnaire included questions that assessed the attitude of mothers towards expressed breast feeding like expressing and storing changed the taste, composition of breast milk, if pumping milk was a time taking procedure, cumbersome, stressful, embarrassing, risky and if electric pumps work better than manual expression, pumping equipment was very expensive, if formula milk was simpler and better option than expressed milk for working women and if women felt their jobs were at stake if they expressed at working hours. Every positive response was scored as 1 and response that indicated negative attitude was scored 0 .
The last part of the questionnaire aimed at knowing the current feeding practices in the absence of the mothers and identifying the barriers against expressed breast feeding in those who did not practise it.

\section{Statistical analysis}

The data obtained was processed using Microsoft Excel software for data entry and statistical analysis was done using Statistical Package for Social Software (SPSS). Chi square test was applied to know the association between variable. $\mathrm{P}$ value less than or equal to 0.05 was considered statistically significant.

\section{RESULTS}

\section{Baseline characteristics of study population}

Table 1: Socio demographic characteristics of participants.

\begin{tabular}{|c|c|c|c|}
\hline Characteristics & Categories & n & $\%$ \\
\hline \multirow{3}{*}{$\begin{array}{l}\text { Age of mother } \\
\text { (years) }\end{array}$} & $<25$ & 10 & 10 \\
\hline & $26-35$ & 80 & 80 \\
\hline & $>35$ & 10 & 10 \\
\hline \multirow{2}{*}{$\begin{array}{l}\text { Infants age when } \\
\text { mother returned } \\
\text { to work (months) }\end{array}$} & $0-6$ & 41 & 41 \\
\hline & 6-12 & 59 & 59 \\
\hline \multirow{4}{*}{ Religion } & Hindu & 73 & 73 \\
\hline & Muslim & 13 & 13 \\
\hline & Christian & 11 & 11 \\
\hline & Jain & 03 & 03 \\
\hline \multirow{5}{*}{ Educational level } & Uneducated & 06 & 06 \\
\hline & Primary schooling & 03 & 03 \\
\hline & Secondary schooling & 12 & 12 \\
\hline & Graduate & 47 & 47 \\
\hline & Postgraduate & 32 & 32 \\
\hline \multirow{11}{*}{$\begin{array}{l}\text { Mother's } \\
\text { occupation }\end{array}$} & Software Engineers & 37 & 37 \\
\hline & Doctors & 11 & 11 \\
\hline & Nurses & 10 & 10 \\
\hline & Teachers & 06 & 06 \\
\hline & Business Women & 04 & 04 \\
\hline & Sales girl & 05 & 05 \\
\hline & $\begin{array}{l}\text { Accountants and bank } \\
\text { employees }\end{array}$ & 07 & 07 \\
\hline & Housemaids & 08 & 03 \\
\hline & Security guards & 04 & 04 \\
\hline & Librarian & 02 & 02 \\
\hline & Others & 06 & 06 \\
\hline \multirow{3}{*}{$\begin{array}{l}\text { Number of } \\
\text { children }\end{array}$} & 1 & 57 & 57 \\
\hline & 2 & 34 & 34 \\
\hline & 3 & 09 & 09 \\
\hline \multirow{3}{*}{$\begin{array}{l}\text { Socio economic } \\
\text { status }\end{array}$} & Upper & 24 & 24 \\
\hline & Middle & 55 & 55 \\
\hline & Lower & 21 & 21 \\
\hline
\end{tabular}

A total of 100 breastfeeding working postnatal women with infants less than 1 year were finalised as the study participants. Their socio demographic characteristics are 
represented in Table 1. Their age ranged between 21 and 39 with mean age being $33.02 \pm 5.59 \%$ of infants were between the age 6-12 months and most $(57 \%)$ were the first children of these mothers. Majority (73\%) were Hindus by religion. Most of them were university graduates $(47 \%)$ and postgraduates $(32 \%)$. About $55 \%$ belonged to middle socio-economic class. Study participants belonged to several professions of whom software engineers were maximum $(37 \%)$.

\section{Knowledge of working mothers about expressed breast milk feeding}

Working women who have satisfactory knowledge regarding expressed breast milk feeding are $36 \%$. Sadly, a majority, $64 \%$ of working women had unsatisfactory knowledge regarding the healthy option of expressed breast milk feeding for their infants.

Table 2: Knowledge regarding expressed breast feeding among participants.

\begin{tabular}{|c|c|c|}
\hline Statements & Right answer (n) & Right answer (\%) \\
\hline \multicolumn{3}{|l|}{ Pumping related knowledge } \\
\hline Breast milk can be pumped and stored and given to babies & 68 & 68 \\
\hline Electric pumps are more effective in pumping than manual pumps & 68 & 68 \\
\hline Dual electric pumps are available to save time while pumping at work & 42 & 42 \\
\hline Breast milk can be stored at room temperature for $4-8 \mathrm{hrs}$ & 34 & 34 \\
\hline Breast milk can be stored in refrigerator for 3 days & 32 & 32 \\
\hline Breast milk can be stored at deep freezer for 6 months & 36 & 36 \\
\hline $\begin{array}{l}\text { Breast milk be stored in BPA free hard plastic containers and sterile Plastic } \\
\text { bags sold for this purpose }\end{array}$ & 40 & 40 \\
\hline $\begin{array}{l}\text { Thawing of stored breast milk by placing in fridge first then in a bowl of } \\
\text { warm water of room temperature. }\end{array}$ & 48 & 48 \\
\hline \multicolumn{3}{|l|}{ Benefits to baby } \\
\hline Breast milk is easy to digest & 72 & 72 \\
\hline Breast milk fed babies have less colic & 70 & 70 \\
\hline Breast milk fed babies have lesser diarrhea/ constipation & 62 & 62 \\
\hline Breast milk provides immunity to baby & 76 & 76 \\
\hline Breast milk protects against allergies and asthma & 30 & 30 \\
\hline Breast milk increases baby IQ & 30 & 30 \\
\hline Babies have good sleep after adequate breast milk feed & 38 & 38 \\
\hline \multicolumn{3}{|l|}{ Benefits to mother } \\
\hline $\begin{array}{l}\text { Expressing breast milk will help her return to and maintain prepregnancy } \\
\text { weight }\end{array}$ & 34 & 34 \\
\hline Expressing breast milk will prevent engorgement & 62 & 62 \\
\hline Pumping increases and maintains mother's milk production & 32 & 32 \\
\hline \multicolumn{3}{|l|}{ Feeding practices } \\
\hline Breast milk fed babies gain weight adequately & 30 & 30 \\
\hline Cow's milk should not be fed to babies till 1 year age & 26 & 26 \\
\hline
\end{tabular}

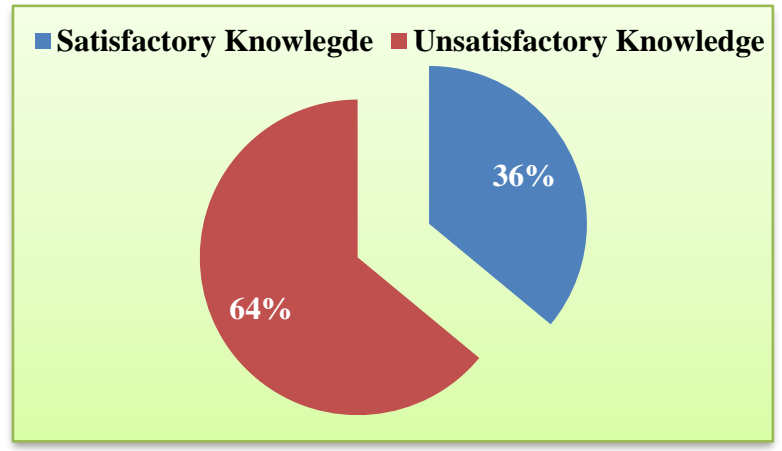

Figure 1: Knowledge regarding expressed breast milk feeding among working mothers.

\section{Working mothers' attitude about expressed breast milk feeding}

A majority (60\%) of working women had positive attitude towards expressed breast milk feeding and those with negative attitude were $40 \%$.

\section{Current feeding practices}

Expressed breast milk feeding was practised by $11 \%$ of working women who attended our postnatal clinic, formula milk feeding was done by $53 \%$ and mixed feeding by $10 \%$ as a substitute to breast feeding in their absence during work hours. 
Surprisingly, cow milk feeding was done by a big number of $26 \%$.

\section{Determinants of expressed breast milk feeding}

None of the socio demographic characteristics could determine the knowledge, attitude and practices regarding expressed breast milk feeding in a statistically significant manner.

The detailed values as observed have been represented in Table 4.

Table 3: Attitude towards expressed breast milk.

\begin{tabular}{|c|c|c|}
\hline Statement & Agree (n) & Disagree (n) \\
\hline $\begin{array}{l}\text { It is best to stop breast feeding when we go back to work after maternity leave and give } \\
\text { formula milk. }\end{array}$ & 18 & 82 \\
\hline Breast milk taste changes after expressing and storing which babies will not like & 26 & 74 \\
\hline It is too cumbersome to express breast milk, freeze and thaw & 79 & 21 \\
\hline It is too risky to give expressed milk. & 62 & 38 \\
\hline Breast milk loses all its nutrition by expressing, freezing and thawing & 40 & 60 \\
\hline $\begin{array}{l}\text { The equipments required for expressed breast milk feeding is very expensive compared } \\
\text { to formula feeding }\end{array}$ & 52 & 48 \\
\hline It is embarrassing to pump breast milk at work place. & 44 & 56 \\
\hline Pumping, freezing and thawing is a very time-consuming process & 72 & 28 \\
\hline It is difficult to concentrate on work because of pumping milk at workplace & 63 & 27 \\
\hline Job will be at stake because of absence from work during the time of pumping. & 23 & 77 \\
\hline $\begin{array}{l}\text { Expressed breast milk feeding is very stressful to the mother as compared to formula } \\
\text { feeding }\end{array}$ & 81 & 19 \\
\hline
\end{tabular}

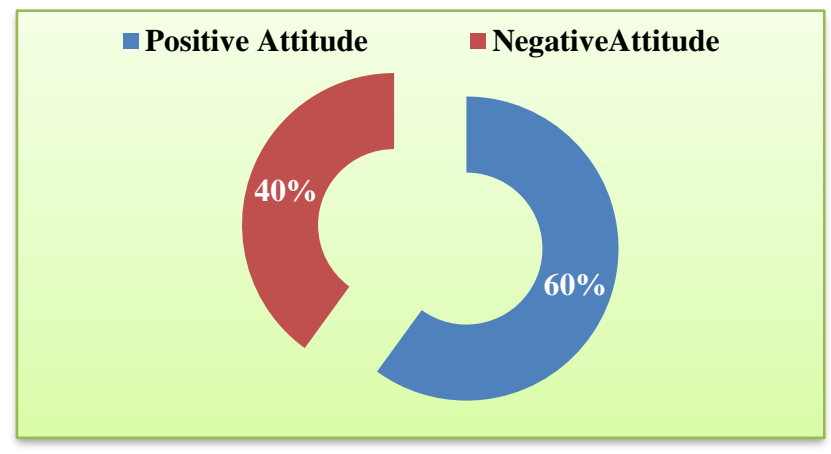

Figure 2: Attitude towards expressed breast milk feeding among working mothers.

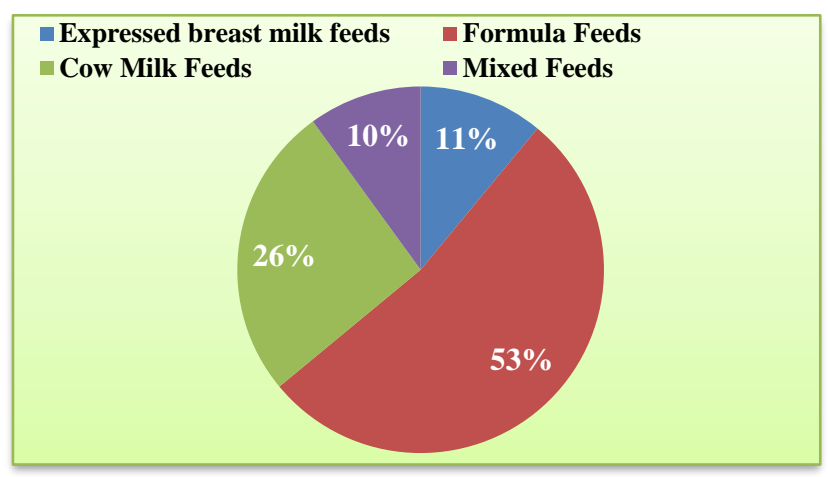

Figure 3: Current feeding practices among working mothers.

\section{Barriers against expressed breast milk feeding}

Several reasons were identified among working mothers against expressed breast milk feeding of their infants in their absence when at work place of which the commonest $(22 \%)$ was lack of knowledge regarding this option. Many women (19\%) also were afraid to try it because they felt it was very risky to store and thaw milk. Detailed pictures of these barriers have been represented in Figure 4.

\section{DISCUSSION}

A similar study conducted by Kastusiime and Ruth reported $71 \%$ of women in Uganda had satisfactory knowledge which is much higher than Indian women of whom $36 \%$ had adequate knowledge according to present study. ${ }^{9}$ According to a study conducted at Miraj, Maharashtra, expressed breast milk feeding was practised by $17.9 \%$ of women but for various reasons. ${ }^{10}$ Present study found $11 \%$ of working women practised it due to their absence for the sake of employment.

Today, duration of exclusive breast feeding is significantly shortened primarily due to maternal return to work. ${ }^{11}$

According to present study, poor knowledge has been identified as the most important barrier against practising expressed breast milk feeding by working mothers of 
India. Every effort should be made by health care professionals, lactation consultants to educate working women right at antenatal clinics so that they accept and implement this knowledge postnatally.

Table 4: Determinants of KAP of expressed breast milk feeding.

\begin{tabular}{|c|c|c|c|c|c|c|c|c|c|c|c|}
\hline & \multicolumn{3}{|l|}{ Knowledge } & \multicolumn{3}{|l|}{ Attitude } & \multicolumn{5}{|c|}{ Practices } \\
\hline & Unsatisfactory & Satisfactory & $\begin{array}{l}\mathrm{P} \\
\text { value }\end{array}$ & Negative & Positive & $\begin{array}{l}\mathrm{P} \\
\text { value }\end{array}$ & $\mathrm{EBF}$ & Formula & $\begin{array}{l}\text { Cow } \\
\text { milk }\end{array}$ & Mixed & $\begin{array}{l}\mathrm{P} \\
\text { value }\end{array}$ \\
\hline \multicolumn{12}{|l|}{ Mothers' age } \\
\hline$<25$ & 7 & 3 & \multirow{3}{*}{0.713} & 6 & 4 & \multirow{3}{*}{0.331} & 0 & 4 & 6 & 0 & \multirow{3}{*}{0.632} \\
\hline $25-35$ & 50 & 30 & & 32 & 46 & & 8 & 44 & 19 & 9 & \\
\hline$>35$ & 7 & 3 & & 2 & 10 & & 3 & 5 & 1 & 1 & \\
\hline \multicolumn{12}{|l|}{ Infants' age } \\
\hline $\begin{array}{l}<6 \\
\text { Months }\end{array}$ & 36 & 16 & \multirow{2}{*}{0.423} & 24 & 28 & \multirow{2}{*}{0.355} & 4 & 30 & 16 & 2 & \multirow{2}{*}{0.399} \\
\hline $\begin{array}{l}>6 \\
\text { Months }\end{array}$ & 28 & 20 & & 16 & 32 & & 7 & 23 & 10 & 8 & \\
\hline \multicolumn{12}{|c|}{ Mother's education status } \\
\hline Uneducated & 6 & 0 & \multirow{3}{*}{0.313} & 6 & 0 & \multirow{3}{*}{0.093} & 0 & 0 & 6 & 0 & \multirow{3}{*}{0.073} \\
\hline Primary & 3 & 0 & & 2 & 2 & & 0 & 0 & 3 & 0 & \\
\hline Postgraduate & 18 & 14 & & 6 & 26 & & 7 & 15 & 6 & 4 & \\
\hline \multicolumn{12}{|c|}{ Socio economic status } \\
\hline Upper & 20 & 2 & \multirow{3}{*}{0.108} & 14 & 8 & \multirow{3}{*}{0.151} & 1 & 7 & 14 & 2 & \multirow{3}{*}{0.063} \\
\hline Middle & 30 & 24 & & 20 & 34 & & 7 & 32 & 8 & 8 & \\
\hline Lower & 14 & 10 & & 6 & 18 & & 3 & 14 & 4 & 0 & \\
\hline \multicolumn{12}{|l|}{ Children } \\
\hline One & 32 & 20 & \multirow{3}{*}{0.293} & 20 & 32 & \multirow{3}{*}{0.321} & 7 & 34 & 11 & 5 & \multirow{3}{*}{0.358} \\
\hline Two & 24 & 16 & & 14 & 26 & & 3 & 18 & 8 & 5 & \\
\hline Three/more & 8 & 0 & & 6 & 2 & & 1 & 1 & 7 & 0 & \\
\hline
\end{tabular}

Figure 4: Barriers against expressed breast milk feeding among working mothers.



It is important to counsel that breast milk is far more superior to formula milk nutritionally for infants. When it is expressed, stored and thawed in the correct method it retains most of its nutrients and properties. It is a natural liquid that is so complexly designed by individual mother for her individual infant that can never be replicated in a factory. It is rich in antibodies and thus it strengthens the immune system of the baby lowering the chances of ear infections, diarrhoea, respiratory infections and meningitis which are commoner among formula fed babies. It also protects against asthma and other allergies, obesity, diabetes and SIDS. ${ }^{12,13}$

It is very easily digested by babies as compared to formula milk, thus reducing the incidence of digestive issues like colic, constipation, diarrhoea and reflux especially in premature babies.

As breast milk comprises of $88 \%$ water, it keeps the breastfed baby well hydrated too. ${ }^{14}$ Several studies have proven that babies who are breastfed have higher IQ than children who are formula fed. ${ }^{15}$ It is believed that breastfed babies are exposed to different tastes depending on the mother's diet each day making them more ready for solid food and good eaters at a later date.

Lactation helps the mother by burning plenty of calories, promote uterine involution, reducing the risk of breast cancer, hypertension, diabetes and cardiovascular diseases. The only nutrient lacking in breast milk which is present in formula milk is vitamin D. But, it can be easily substituted. AAP recommends vitamin D supplementation for the first 2 months in exclusively breastfed babies. ${ }^{16}$ 
For all the above-mentioned advantages, it is understood that breast milk as far as possible should not be substituted by formula milk. A very smart alternative for working mothers is expressed breast milk. Milk can be pumped either manually or with the help of a pump and stored in BPA free plastic storage containers or sterile plastic bags made for this purpose.

At room temperature, it can be given within 4 hours in moderately warm places and within $8 \mathrm{hrs}$ in cooler places. When stored in the refrigerator at $4^{\circ} \mathrm{C}$, they should be used within 3 days and in the deep freezer by 6 months. Prior to administering it to the baby, they need to be thawed by placing them in lukewarm water and when in the freezer they need to be shifted to the refrigerator first and then placed in lukewarm water. ${ }^{17,18} \mathrm{~A}$ few disadvantages include the high cost of the pump and storage bags, time that needs to be dedicated for pumping and sterilising the equipment and need for a private place to pump. ${ }^{19}$

Analysing the barriers against expressed breast milk, we understand that most women did not know that such an option was available. Also, many of them were afraid to try it because they thought it was very risky. Both of these obstacles can be overcome by healthcare professionals and lactation consultants educating working women about all the feeding options, their pros and cons and reassure them adequately. Few of them opined that the milk they produced was not enough to be pumped. Pumping steadily increases breast milk production making the milk adequate for that individual baby. ${ }^{20,21}$

For women who are in short of time electric pumps especially dual pumps although more expensive, work easier and faster as compared to manual pumps. ${ }^{22}$ For those who find the equipment expensive, recent Cochrane review suggests that low cost pumps and manual expression are equally or could even be more effective as electric pumps. It also further states that there is no difference in the amount of milk produced between manual expression and electric pump expression. ${ }^{23}$ Imparting adequate knowledge will be the effective solution to lead working mothers to the path of right practices so that the nation shall achieve and maintain breastfeeding goals and curb infant and neonatal morbidity and mortality.

\section{CONCLUSION}

In conclusion, the knowledge about expressed breast milk feeding among Indian working breastfeeding mothers is suboptimal.

- Healthcare professionals and lactation consultants can counsel working women from antenatal period onwards so that these women can utilise it after delivery.

- Government can sensitize general public through educative advertisements about this feeding option
- Hospitals can prepare written policies to educate and change people's attitude towards expressed milk feeding to a more positive one so that there will be a change in current feeding practices.

- Employers can initiate breastfeeding place and time related policies at workplaces so that women can continue breast milk feeding comfortably.

\section{ACKNOWLEDGMENTS}

The Author would like to thank Mr Nirmal Surekutchi, the chief interviewer of the study for spending his valuable time for data collection.

Funding: No funding sources

Conflict of interest: None declared

Ethical approval: The study was approved by the Institutional Ethics Committee

\section{REFERENCES}

1. Lessen R, Kavanagh K. Position of the academy of nutrition and dietetics: promoting and supporting breastfeeding. J Acad Nutr Diet. 2015;115:444-9.

2. USAID A. University of California Davis. Indicators for assessing infant and young child feeding practices. Geneva: WHO;2008. Available at http://apps.who.int/iris/bitstream/10665/43895/1/978 9241596664_eng.pdf

3. UNICEF. The global strategy on infant and young child feeding (GSIYCF) understanding the past planning the future. Available at: https://www.unicef.org/nutrition/files/FinalReporton Distribution.pdf

4. Witters-Green R. Increasing breastfeeding rates in working mothers. Families Systems Health. 2003;21(4):415.

5. Infant and Young Child Nutrition. Available at http://apps.who.int/gb/archive/pdf_files/WHA55/ea5 515.pdf. Accessed on 14 November 2012.

6. Institute of Medicine of the National Academics. infant formula: evaluating the safety of new ingredients. The National Academics Press. Washington, DC, USA;2004

7. Ortiz J, McGilligan K, Kelly P. Duration of breast milk expression among working mothers enrolled in an employer-sponsored lactation program. Pediatr Nurs. 2004;30(2):111-9.

8. Biagioli F. Returning to work while breastfeeding. Am Fam Physician. 2003;68(11):2201-8.

9. Katusiime R. Knowledge, attitude and practice of expressed breast milk feeding among working mothers of infants aged 0-6 months attending maternal child health clinic at upper Mulago National Referral Hospital, Kampala District. 2016. Available at http://catalog.ihsu.ac.ug:8585/cgibin/koha/opac-detail.pl?biblionumber=6431.

10. Prabhu PM, Radhe BK, Naik JD, Brahmankar TR, Behere VS. Knowledge, Attitude and Practice of Expression of Breast Milk among Mothers in 
Western Maharashtra. J Med Sci Clin Res. 2016;4(1):8828-34.

11. Ong G, Yap M, Li FL, Choo TB. Impact of working status on breastfeeding in Singapore. The European Journal of Public Health. 2005;15(4):424-30.

12. Harfouche JK. The importance of breast-feeding. Journal of Tropical Pediatrics. 1970;16:135-75.

13. World Health Organization, UNICEF. Protecting, promoting and supporting breast-feeding: the special role of maternity services. 1989. Availabe at http://www.who.int/nutrition/publications/infantfeedi ng/9241561300/en/

14. Johns HM, Forster DA, Amir LH, McLachlan HL. Prevalence and outcomes of breast milk expressing in women with healthy term infants: a systematic review. BMC Pregnancy Childbirth. 2013;13(1):212.

15. Lucas A, Morley R, Cole TJ, Lister G, Leeson-Payne C. Breast milk and subsequent intelligence quotient in children born preterm. Lancet. 1992;339(8788):261-4.

16. Holick MF, Chen TC. Vitamin D deficiency: a worldwide problem with health consequences. The American journal of clinical nutrition. 2008;87(4):1080S-6S.

17. Ajusi JD, Onyango FE, Mutanda LN. Bacteriology of unheated expressed breast milk stored at room temperature. East African Med J. 1989;66(6):381-7.
18. Slutzah M, Codipilly CN, Potak D, Clark RM, Schanler RJ. Refrigerator storage of expressed human milk in the neonatal intensive care unit. J Pediatr. 2010;156(1):26-8.

19. Ryan AS, Zhou W, Arensberg MB. The effect of employment status on breastfeeding in the United States. Women's Health Issues. 2006;16(5):243-51.

20. Slusher T, Slusher IL, Biomdo M, Bode-Thomas F, Curtis BA, Meier P. Electric breast pump use increases maternal milk volume in African nurseries. Journal of tropical pediatrics. 2007;53(2):125-30.

21. Morton J, Hall JY, Wong RJ, Thairu L, Benitz WE, Rhine WD. Combining hand techniques with electric pumping increases milk production in mothers of preterm infants. J Perinatol. 2009;29(11):757-64.

22. Walker M, Auerbach KG. Breast pumps and other technologies. Breastfeeding Human Lactation. 1999;2:393-448.

23. Becker GE, Cooney F, Smith HA. Methods of milk expression for lactating women. Cochrane Database Syst Rev. 2011;12:CD006170.

Cite this article as: Rai S. Expressed breast milk: a less used option by working mothers of India. Int J Reprod Contracept Obstet Gynecol 2017;6: 2867-73. 